\title{
A TARTOMÁNYI RENDSZER ÉS \\ A NEMZETI KÉRDÉS ROMÁNIÁBAN 1950-1968
}

\author{
(Province-system and National-question in Romania \\ 1950-1968)
}

\author{
GULYÁS LÁSZLÓ
}

Kulcsszavak:

közigazgatási térfelosztás rajon nemzeti kérdés romániai magyar kisebbség

Közép-Európa első világháború utáni új térfelosztásának egyik fontos, de kevésbé ismert jellemzője, hogy a területi folyamatok egyik legnagyobb nyertese a román állam volt, melynek területe az 1914. évi 139,1 ezer $\mathrm{km}^{2}$-röl 1920-ra 295,9 ezer $\mathrm{km}^{2}$-re nött, azaz a román állam 156,8 ezer $\mathrm{km}^{2}$ területi nyereséget könyvelhetett el a közép-európai átrendezödés következtében. Az igy megszületö Nagy-Románia egyik kulcskérdése a közigazgatási térfelosztás, melynek jelentőségét jól mutatja, hogy a 20. század folyamán a román politikai elit 12 alkalommal hajtott végre közigazgatási reformot (1926, 1929, 1936, 1938, 1950, 1952, 1956, 1960, 1968, 1981, 1991, 1998). Ezek a közigazgatási reformok általában a megyerendszert próbálták megreformálni.

Jelen tanulmány a szocialista korszak azon négy közigazgatási reformját (1950, 1952, 1956, 1960) elemzi, melyek a megye helyett tartományi rendszert akartak Románián belül müködtetni, illetve a tanulmány záró részében röviden kitér az 1968. évi reformra, mely visszaállitotta a megyerendszert.

\section{Elözmények}

1944 és 1948 között Romániában demokratikus kísérlet zajlott (a politikai életben többpártrendszerrel, a gazdasági életben jelentős magántulajdonnal), de a román kommunisták 1948-ban a Szovjetunió támogatásával véget vetettek ennek a kísérletnek. 1948. február 21-23-án a Román Kommunista Párt és a Szociáldemokrata Párt egyesítő kongresszusán kimondták a két párt egyesülését, s megalakult a Román Munkáspárt (RMP). A két párt egyesülése az egyik legfontosabb lépésnek tekinthető a sztálini típusú totalitárius modell megteremtése felé (Balogh 2001). Az RMP saját totális uralmának kiépítése érdekében az egyesítő kongresszus után még keményebben folytatta az osztályharcot. Ennek főbb területei az alábbiak voltak (Réti 1990): a politikai életben az egypártrendszer kiépítése, a pluralitás felszámolása, az ipari szektorban az államosítás, majd ezt követően központosított, tervutasításon nyugvó erőltetett ütemü, nehéziparra koncentráló gazdaságfejlesztési politika, míg a mezőgazdaságban erőszakos kollektivizálás.

Témánk - azaz a közigazgatási térfelosztás és a nemzeti kérdés összefüggései - kiindulási pontja 1948 áprilisa, amikor az RMP új alkotmányt léptetett életbe. Ezen alkotmány közigazgatási szempontból azonban még a régi, azaz a két világháború közötti megoldást éltette tovább, vagyis a megye-rendszerre épült. Ennek megfelelően Romániát 58 megyére, 424 járásra és 6248 községre osztotta fel (Vokfori 1994; 1996). 


\section{A rajonálási törvény, avagy az 1950. évi reform}

A totális rendszert építő Román Munkáspárt Központi Vezetősége (RMP KV) és a Minisztertanács 1950 júliusában közös ülést tartott, melynek egyetlen napirendi pontja a közigazgatási térfelosztás kérdése volt. Ezen a júliusi tanácskozáson arra a megállapításra jutottak, hogy az ország területi megszervezése nem felel meg a politikai és gazdasági feltételeknek, mert fékezi a népi demokratikus rendszer fejlődését a szocializmus építésének útján, ezért fel kell számolni a megye-rendszert és helyette tartományi és ezen belül ún. rajon-rendszert kell bevezetni (Réti 1990; Balogh 2001).

Ilyen előzmények után léptették életbe 1950. szeptember 6-án az 1950/5. számú rajonálási törvényt (Miklós 1961), mely teljes mértékben átrajzolta Románia belső közigazgatását: 58 megye helyett 28 tartományt állított fel, melyet 177 rajonra, 360 járásra és 4052 községre tagoltak (1. ábra), azaz felszámolta a megyerendszert és a korábbi háromszintü közigazgatás helyett négy közigazgatási szintet határozott meg. A legalsó szint a község volt, ez egy vagy több, egymáshoz közel lévő faluból állt össze, átlagban 3 ezer lakossal. A következő szint a város volt, mely jelentős politikai, közigazgatási, ipari, kereskedelmi funkciókat töltött be. A rajon több várost és községet zárt keretei közé, tervezési, gazdasági, politikai és közigazgatási szempontból operatív területi egységként kívánták müködtetni. A tartomány több rajont fogott össze, és ily módon erős közigazgatási területi egység szerepét kellett volna betöltenie.

\section{1. ÁBRA}

Románia tartományai 1950-1952

(Province-system in Romania 1950-1952)

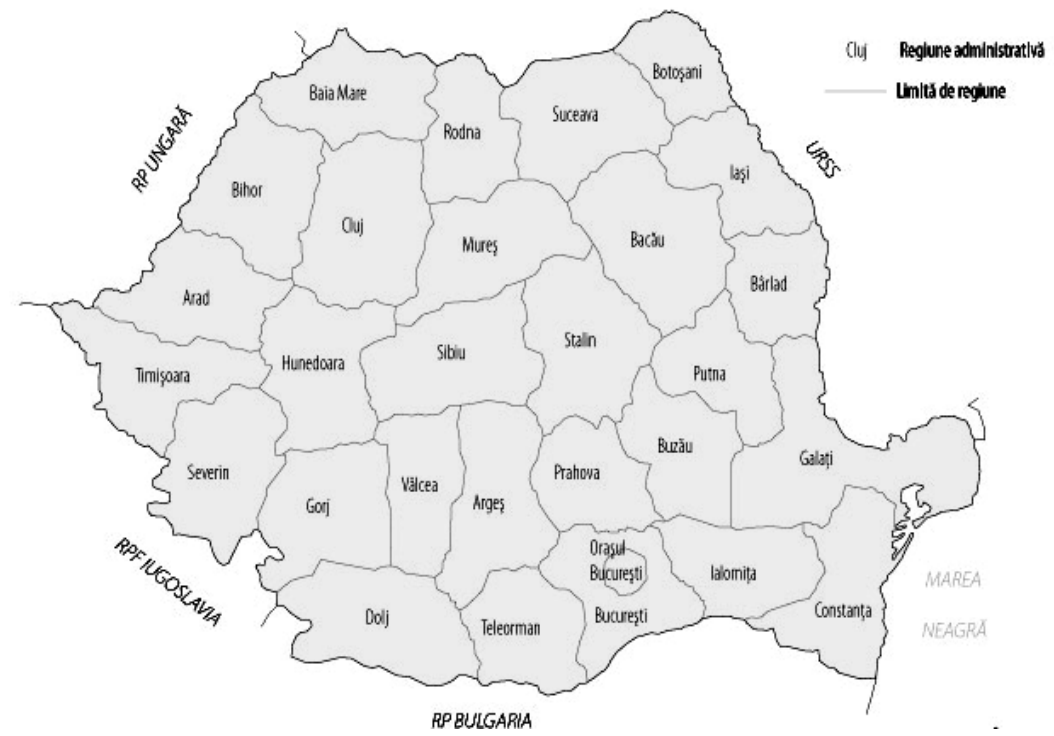

Forrás: http://www.mdlpl.ro/_documente/atlas/. 
Joggal merül fel a kérdés, hogy a román kommunisták miért döntöttek úgy, hogy a több száz éves megye-rendszert tartományi, illetve ezen belül rajon rendszerré alakítják át. A kérdésre kétfajta válasz adható, egyrészt az akkori hivatalos román válasz, másrészt a valódi okokat feltáró válasz. A hivatalos válasz az RMP KV állásfoglalásából teljes mértékben rekonstruálható, eszerint a rajon rendszer bevezetése mellett az alábbi érvek szóltak (Molnár 1992):

- A megye-rendszer a tőkés-földesúri rezsim fontos eleme, és mint ilyen kifejezetten a kizsákmányoló osztályok érdekeit szolgálja.

- A megyék területe és lakosságszáma között nagy eltérések vannak.

- A megyék fejlettségi szintje nagyon különböző.

- A megyeszékhelyek kiválasztásánál a régi uralkodó osztály kifejezetten kerülte a munkásközpontokat, a munkásvárosokat.

- A megyehatárok földrajzilag egységes területeket vágnak ketté.

Mindezen hibák orvoslására az RMP KV a szovjet, ún. rajon modell átvételét tartotta alkalmasnak. A valódi válasz azonban a fenti indoklástól némileg eltér, bár a kétfajta válasz között azért rögzíthetünk átfedést. Valójában a rajon-rendszer bevezetése kifejezetten szovjet nyomásra és szovjet mintára történt Romániában. Itt kell felhívnunk a figyelmet arra, hogy az 1945-ben szovjet érdekszférába került középés kelet-európai országok politikai és gazdasági életébe a Szovjetunió rendszeresen és nagy mértékben beavatkozott. A szovjet vezetők a helyi - értsd az adott ország kommunista politikai elitjét rendszeresen Moszkvába rendelték konzultációra, pontosabban eligazításra. Míg magán az adott országon belül az ott állomásozó szovjet tanácsadók a helyszínen instruálták őket. A szovjet hadsereg és belügyi szervek térségbeli jelenléte pedig megkérdőjelezhetetlenné tette ezen szisztéma müködtetését. Az 1953. évi berlini munkás felkelés, a magyarországi 1956-os forradalom és az 1968. évi prágai tavasz fejleményei kiváltották a szovjet katonai beavatkozást.

A közép-kelet-európai országok gazdasági és politikai életébe történő szovjet beavatkozás súlyát és mélységét jól mutatja, hogy Stefano Bottoni kutatásai során arra a felfedezésre jutott, hogy az 1950-es rajonálási törvényhez felhasznált szakértői anyagok a Szovjetunióból már románra fordítva érkeztek meg az RMP-hez (Bottoni 2005). Itt kell felhívnunk a figyelmet arra, hogy a román belügyekbe történő szovjet beavatkozás korántsem volt példa nélküli, gondoljunk arra, hogy Sztálin sajátkezüleg szerkesztette át a lengyel alkotmányt, vagy arra, hogy az 1950-es években a soros magyar miniszterelnököt rendszeresen Moszkva jelölte ki.

Az 1950. évi közigazgatási reformmal - továbbá az 1952. évi reformmal - foglalkozó különféle szerzők tanulmányait (Bárdi 2005) áttekintve jelen tanulmány szerzője arra a következtetésre jutott, hogy a Szovjetunió beavatkozása mögött három komoly szándék húzódott meg:

1. Sztálin gyors és erőszakos modernizációt akart véghezvinni az érdekszférájába került közép-kelet-európai országokban. Ezen törekvés két legfontosabb eleme az iparosítás és a városiasodás felgyorsítása volt (A. Gergely 1988). 
2. A közigazgatási átszervezés lehetőséget teremtett a „régi központok és régi emberek” - a „régi” a kommunista szótárban a „megbízhatatlan” szinonimája volt - lecserélésére (Gagyi 2005a; 2005b; 2005c).

3. A romániai nemzeti kérdés - pontosabban a magyar kisebbség kérdésének - rendezése.

Nézzük meg, hogy a fenti három sztálini szándék hogyan teljesült az 1950. évi reform esetében. Ha az első szándékot vizsgáljuk, akkor azt rögzíthetjük, hogy az új közigazgatási határok meghúzásánál és az új tartományi- és rajonközpontok kiválasztásánál a gazdasági szempontok játszották a föszerepet. A kijelölt közigazgatási és rajon központokat a román kommunisták megpróbálták tényleges központokká fejleszteni, illetve szintén megpróbálkoztak a területi fejlettségbeli különbségek csökkentésével.

A második szándékot vizsgálva a régi központok - értsd régi városok - lecserélésével kapcsolatban azt rögzíthetjük, hogy több komoly történelmi-kulturális múlttal rendelkező város (Nagyszeben, Segesvár, Balázsfalva) a lefokozás sorsára jutott, azaz a kommunisták nem jelölték öket tartományi- és rajon székhellyé, mivel a román kommunista vezetők értékrendjében ezek „polgári” és „,reakciós jellegü” települések voltak. Például Balázsfalva egyházi központként érdemelte ki a ,reakciós” jelzőt. A „régi” központokkal szemben az RMP a „régi rendszerben” - értsd a két világháború között - elhanyagolt munkáskörzeteket és bányatelepüléseket favorizálta (Bottoni 2005). Jól mutatja a közigazgatási reform osztályharcos vonulatát Constantin Parvulescu - az RMP Központi Ellenőrző Bizottságának elnöke - kijelentése, aki szerint a megyéket azért kell „likvidálni”, mert azok a felszámolásra ítélt feudális elmaradottság és elnyomás múltból származó szimbólumai és maradványai (Bottoni 2008). A második szándék humán erőforrás oldalát - azaz a káderpolitikát - vizsgálva azt láthatjuk, hogy a közigazgatási reform a helyi káderek körében nagyarányú személycserékkel járt (Gagyi 2005a; 2005b; 2005c).

\section{TÁBLÁZAT}

Románia és Erdély népességének etnikai megoszlása 1948-ban (Ethnic Breakdown in Romania and Transylvania at 1948)

\begin{tabular}{lcccccc}
\hline & Román & Magyar & Német & Zsidó & Egyéb & Összesen \\
\hline Románia & 13598000 & 1500000 & 344000 & 139000 & 292000 & 15873000 \\
Erdély & 3752000 & 1482000 & 332000 & 30000 & 165000 & 5761000
\end{tabular}

Forrás: Balogh (2001).

A harmadik sztálini szándék - a romániai nemzeti kérdés rendezése - fontosságát jól mutatja, az 1. táblázat, melyből láthatjuk, hogy a mintegy másfél milliós magyar kisebbség Románia összlakosságának 9\%-át, míg Erdély népességének egynegyedét tette ki, azaz a magyar kisebbség kérdése fontos belpolitikai kérdés volt a szocialista Romániában. Míg az első két szovjet szándék többé-kevésbé teljesült az 1950-es közigazgatási reform során, addig a harmadik szándék esetében azt rögzíthetjük, hogy a román komunista vezetők megpróbálták elszabotálni a szovjetek ezen kíván- 
ságát. Azaz a magyar kisebbségi kérdés rendezése során igyekeztek a román érdekeket megvédeni.

Mint az 1. ábráról leolvasható, a 28 tartományból 11 tartomány esett Erdély területére, ezek az alábbiak: Nagybánya (Baia Mare), Radna (Rodna), Bihar (Bihor), Kolozsvár (Cluj), Maros (Mures), Arad (Arad), Hunyad (Hunedoara), Szeben (Sibiu), Sztálin (Stalin), Temesvár (Timisoara), Szörény (Severin). Ezen erdélyi tartományok határait a román kommunisták úgy húzták meg, hogy csökkentsék az adott tartományon belül a magyar kisebbség részarányát. Ennek érdekében az alábbi lépéseket tették (Vokfori 1994; 1996):

- Szörény megyét kettévágták. Egy részéböl kialakították Szörény (Severin) tartományt, míg Lugost és környékét Temes (Timisoara) tartományhoz csatolták.

- A Szilágyságot háromfelé osztották: Szilágysomlyó Bihar (Bihor), Zilah Kolozs (Cluj), míg Szilágycseh Nagybánya (Baia Mare) tartományhoz került.

- Máramaros keleti felét Radna (Rodno) tartományhoz csatolták.

- Gyergyót Maros (Mures) tartományhoz csatolták.

- A négy székely megyét (Maros, Udvarhely, Csík és Háromszék) két tartományba osztották be. Így jött létre Sztálin tartomány (székhelye: Brassó) és Maros tartomány (székhelye: Marosvásárhely).

A fenti lépések következtében Erdély 11 tartományából 9-ben román többség alakult ki, csak két tartományban - Sztálin tartomány (61,8\%) és Maros tartomány (54\%) - alakult ki magyar többség (Bottoni 2008).

A reform során a községek számát is jelentősen csökkentették, 6248-ról 4052-re, azaz több mint 2000 község autonómiáját számolták fel. Ez elsősorban a tömbmagyar területeken kívül elhelyezkedö magyar községeket érintette, hiszen a csökkentés a legtöbb esetben úgy nézett ki, hogy a magyar többségü község autonómiáját szüntették meg és csatolták a román többségü községhez.

\section{A Magyar Autonóm Tartomány időszaka 1952-1960}

A magyar kisebbséggel történő fentebb ismertetett román törekvések nem nyerték el Moszkva tetszését, ezért 1951 nyarán két szovjet tanácsadó - P. Arhipov és P. Tumanov - érkezett Bukarestbe, akik magukhoz rendelték Georgescu román belügyminisztert és arról faggatták, hogy a román vezetők figyelemmel voltak-e a nemzeti kisebbségekre a tartományok határainak kijelölésekor (Bottoni 2008).

A megbeszélés után 1951 szeptemberében a két tanácsadó a „Feljegyzés az Erdélyben létrehozandó magyar autonóm tartományról" címü memorandumot juttatta el az első számú román vezetőhöz, Gheorghiu-Dej-hez. Ebben az anyagban kifejtették, hogy ,figyelembe véve a nemzetiségi közigazgatási területek létrehozásának Szovjetunióbeli gyakorlatát és a nemzetiségi kérdés sajátosságait a Román Népköztársaságban, ajánlatosnak látszik egy Magyar Autonóm Tartomány létrehozása Erdélyben" (Bottoni 2008). Ráadásul a feljegyzés részletes javaslatot tett a felállítandó 
Magyar Autonóm Tartomány határairól is. A román politikai elit nem volt abban a helyzetben, hogy visszautasítsa a fenti szovjet ,javaslatot”, így az 1952. évi újabb román alkotmányba (Hardi-Hajdú-Mezei 2009) - itt jegyezzük meg, hogy ezen alkotmány végleges szövegét szintén Moszkvában fogalmazták meg - bekerült a Magyar Autonóm Terület létrehozásáról rendelkező 19-21. cikkely.

\section{2. ÁBRA}

Románia tartományai 1952-1956

(Province-system in Romania 1952-1956)

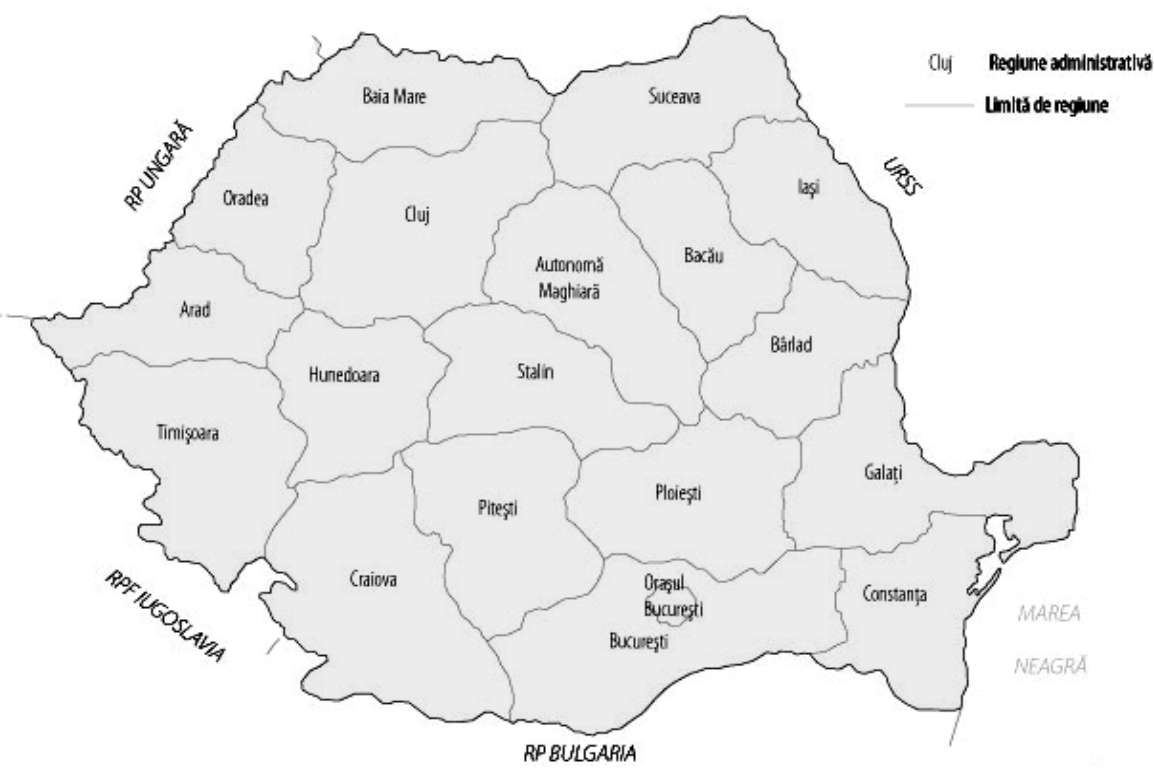

Forrás: Forrás: http://www.mdlpl.ro/_documente/atlas/.

Az 1952. szeptember 21-én kiadott 331. számú törvényerejü rendelet ismét átrajzolta Románia közigazgatását. Az 1. ábra és a 2. ábra összevetéséböl látható, hogy az 1950-ben felállított 28 tartományt lecsökkentették 18 tartományra. A változások az erdélyi tartományokat az alábbi módon érintették (Vokfori 1994; 1996):

- Az erdélyi tartományok száma az 1950. évi 11-röl 8-ra csökkent.

- Radna (Rodna) tartományt felosztották Kolozs (Cluj) és Nagybánya (Baia Mare) között.

- Bihar (Bihor) tartományt átkeresztelték Nagyvárad (Oradea) tartományra.

- Szörény (Severin) tartományt teljes egészében Temesvár (Timisoara) tartományhoz csatolták.

- Szeben (Sibiu) tartományt összevonták Sztálin (Stalin) tartománnyal, és átrajzolták határait.

- Maros (Mures) tartományt megszüntették, pontosabban határait átrajzolva Magyar Autonóm Tartománynak keresztelték át. 
A Magyar Autonóm Tartomány (MAT) egy adminisztratív keretbe egyesítette a történelmi Székelyföldet. A MAT az alábbi 9 rajonból állt: Csík, Gyergyó, Udvarhely, Szászrégen, Erdőszentgyörgy, Sepsiszentgyörgy, Marosvásárhely, Kézdivásárhely, Maroshévíz. Nagyon fontos megjegyeznünk, hogy a MAT-ból kimaradt az 55\%-ban magyarlakta Rákos rajon, de ezzel szemben bekerült két felső-marosvölgyi román többségü rajon, Szászrégen és Maroshéviz (Toplica), amelyek nem tartoztak a történelmi Székelyföldhöz.

\section{TÁBLÁZAT}

A MAT lakossága nemzetiség szerint (1956) (Ethnic Breakdown of MAT [1956])

\begin{tabular}{|c|c|c|c|c|c|c|}
\hline & $\begin{array}{c}\ddot{O}_{s s z l a-} \\
\text { kosság } \\
(f o ̈)\end{array}$ & $\begin{array}{c}\text { Magyar } \\
(\%)\end{array}$ & $\begin{array}{c}\text { Román } \\
(\%)\end{array}$ & $\begin{array}{c}\text { Cigány } \\
(\%)\end{array}$ & $\begin{array}{c}\text { Német } \\
(\%)\end{array}$ & $\begin{array}{l}\text { Zsidó } \\
(\%)\end{array}$ \\
\hline $\begin{array}{l}\text { Marosvásárhely } \\
\text { municípium }\end{array}$ & 65194 & 73,7 & 22,4 & 0,3 & 0,4 & 2,8 \\
\hline $\begin{array}{l}\text { Marosvásárhely } \\
\text { rajon }\end{array}$ & 85516 & 75,4 & 20,1 & 3,5 & 0,1 & 0,1 \\
\hline Csík rajon & 84879 & 95,4 & 3,8 & 0,4 & 0,2 & 0,1 \\
\hline Gyergyó rajon & 55305 & 88,9 & 9,6 & 0,3 & 0,1 & 0,1 \\
\hline Udvarhely rajon & 81668 & 98,1 & 1,4 & 0,3 & 0,1 & 0,1 \\
\hline Régen rajon & 92257 & 32,9 & 62,0 & 2,4 & 1,9 & 0,6 \\
\hline Sepsiszentgyörgy & 77343 & 85,2 & 11,2 & 2,4 & 0,4 & 0,1 \\
\hline $\begin{array}{l}\text { Erdőszentgyörgy } \\
\text { rajon }\end{array}$ & 52995 & 92,0 & 6,2 & 1,0 & 0,5 & 0,1 \\
\hline $\begin{array}{l}\text { Kézdivásárhely } \\
\text { rajon }\end{array}$ & 67747 & 90,0 & 7,4 & 2,2 & 0,1 & 0,1 \\
\hline $\begin{array}{l}\text { Maroshévíz } \\
\text { rajon }\end{array}$ & 39370 & 25,0 & 72,2 & 1,4 & 0,2 & 0,5 \\
\hline Székelykeresztúr* & 26113 & 97,9 & 0,6 & 1,3 & 0,1 & 0,1 \\
\hline Összesen & 731387 & 77,35 & 20,1 & 1,5 & 0,4 & 0,4 \\
\hline
\end{tabular}

Forrás: Bottoni $(2008,207)$.

A MAT az 1,6 millió főt számláló romániai magyar kisebbség kb. egyharmadát fogta össze. Erdély további tartományaiban élt a romániai magyarság kétharmad része, az alábbi megoszlásban (Diószegi-R. Süle 1990; Varga 1992):

- A nagybányai tartományban $27,8 \%$, a nagyváradi tartományban $28,5 \%$ volt a magyarok aránya, ez együtt fél millió fót jelentett.

- 200 ezer magyar élt Kolozs tartományban.

- Sztálin tartományban és Hunyad tartományban 100-100 ezer magyar élt.

- Temes tartományban (ezen belül Temesváron) 150 ezer magyar élt.

A MAT 8 éves fennállása (1952-1960) alatt Bukarest arra törekedett, hogy az autonómiát a lehető legkisebbre szorítsa vissza, korlátozza a MAT jogosítványait. Jól mutatja ezt a törekvést, hogy bár az 1952. évi alkotmány értelmében a MAT-nak 
önálló statutumot - azaz alapszabályt - kellett volna kapnia, a statutum a román vezetés ellenállása miatt soha nem készült el.

3. ÁBRA

Románia tartományai 1956-1960

(Province-system in Romania 1956-1960)

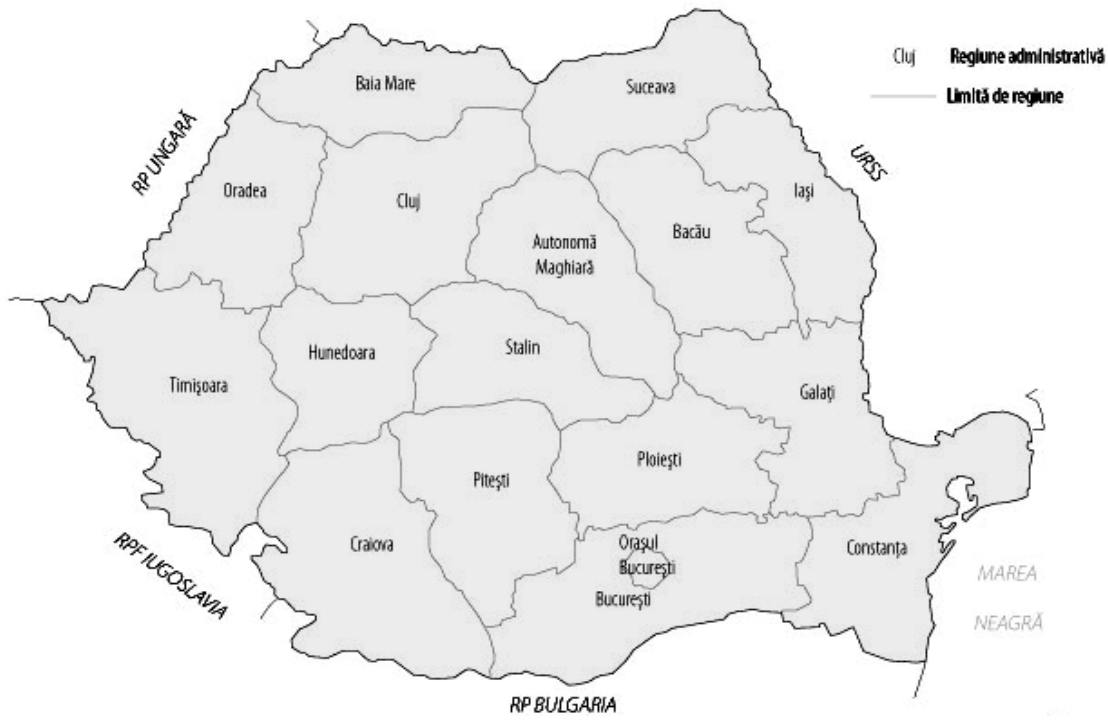

Forrás: http://www.mdlpl.ro/_documente/atlas/.

Sztálin halála után (1953 márciusa) Bukarest megpróbálta a Szovjetuniótól való bel- és külpolitikai függést lazítani. Jól mutatja ezt, hogy Gheorghiu-Dej, az RMP fötitkára 1955 augusztusában jegyzéket intézett Hruscsovhoz, melyben a szovjet csapatok Romániából történő kivonását kérte. Az idők változását jól mutatja, hogy Hruscsov beleegyezett a kívánság teljesítésébe, és 1958-ban a szovjet csapatok valóban kivonultak Romániából.

A román függetlenedési lépések - például a szovjet-román vegyes vállalatok felszámolása - a nemzetiségi politikában is fordulatot hoztak. Egyrészt Bukarest igyekezett megnyirbálni a MAT-ban megtestesülő magyar autonómiát, másrészt komoly támadásokat intézett a MAT keretein kívül élő magyarok ellen. Ezen támadások közül a legfontosabb az volt, hogy 1953. február 19-én feloszlatták a magyarság érdekképviseleti szervét, a Magyar Népi Szövetséget. A kétnyelvü táblák felszámolása, a közigazgatási nyelvhasználat korlátozása, a magyar újságok, a magyar intézmények és iskolák felszámolása egész Erdély területén szisztematikusan zajlott (Diószegi-R. Süle 1990). Érzékenyen érintette a magyar kisebbséget, hogy 1956-tól kezdve elkezdték az iskola összevonásokat (alap- és középfokon), ennek keretében a magyar iskolákat román iskolákkal vonták össze, és így, ún. két-tannyelvü iskolákat hoztak létre (román és magyar tagozattal), melyen belül a későbbiek során megpróbálták a magyar tagozatot elsorvasztani. 
Az iskola összevonás elérte a felsőoktatást is, 1959-ben összevonták a magyar nyelvü kolozsvári Bolyai egyetemet a román nyelvü Babes egyetemmel, így jött létre a Babes-Bolyai egyetem, azaz a felsőoktatásban is megszünt a magyar önállóság (Szesztay 2003).

Az 1956. januári 4-i rendelet ismét módosította a román állam belső felosztását, a tartományok számát 18-ról 16-ra csökkentették oly módon, hogy Arad tartományt felosztották Nagyvárad (Oradea) és Temesvár (Timisoara) tartományok között, míg Barlád (Barlad) területén Bákó (Bacau) és Jászvásár tartomány (Iasi) osztozott meg.

\section{A Maros-Magyar Autonóm Tartomány időszaka 1960-1968}

Az 1956. évi közigazgatási átszervezés csak kismértékben érintette a magyar kisebbséget - Temesvár tartományon belül csökkent a magyarok aránya -, ezzel szemben az 1960. évi újabb közigazgatási átszervezés (4. ábra) már komoly veszteséget jelentett, hiszen átszervezték, gyakorlatilag felszámolták a Magyar Autonóm Tartományt. Az átszervezést, azaz a tartományi határok módosítását - bizonyos rajonok elcsatolása, bizonyos rajonok odacsatolása - gazdaságföldrajzi érvekkel támasztották alá (Vokfori 1994; 1996). Az elcsatolást igazoló érvelés szerint Háromszék gazdaságilag Brassóhoz vonzódik, ezért Kézdivásárhely és Sepsiszentgyörgy rajonokat Brassó (Brasov) tartományhoz - ezt korábban Szálin tartománynak nevezték - kell csatolni. Ez gyakorlatilag azt jelentette, hogy a történelmi Székelyföldet kettévágták és két tartomány között felosztották. Az odacsatolást igazoló érvelés szerint a Mezőség keleti része és a Kis-Küküllő völgye Marosvásárhelyhez vonzódik, ezért Brassó tartomány északnyugati részét (Dicsőszentmárton rajon, amely román többségü) és Kolozs tartomány délkeleti részét (Ludas és Sármás rajonok, amelyek szintén román többségüek) a MAT-hoz kell csatolni.

A határok fenti módosítása után a MAT elnevezés elé odatették a Maros szót és így létrejött a Maros-Magyar Autonóm Tartomány (MMAT, románul Mures Autonoma Maghiara), melynek székhelye Marosvásárhely maradt.

A Bukarest által hangoztatott gazdaságföldrajzi érvek mögött meghúzódó valódi okokra világít rá a 3. táblázat, melyből kiolvasható, hogy az átszervezés után felálló MMAT tartományban a magyarok aránya jelentős mértékben csökkent (76,95\% -ról 61,1\%-ra).

3. TÁBLÁZAT

A MAT és az MMAT nemzetiségi megoszlása (Ethnic Breakdown of MAT and MMAT)

\begin{tabular}{cccc}
\hline & Összlakosság & Magyarok (\%) & Románok (\%) \\
\hline MAT & 759436 fö & $76,9 \%$ & $20,4 \%$ \\
MMAT & 800854 fö & $61,1 \%$ & $35,2 \%$ \\
\hline
\end{tabular}

Forrás: Bottoni $(2008,418)$.

Itt jegyezzük meg, hogy Bukarest az 1960. évi közigazgatási átszervezés során más tartományok esetében is alkalmazta az át- és odacsatolások eszközét. Például 
Kolozsvár esetében 9 román község odacsatolásával Kolozsvárott is román többséget $(50,9 \%)$ alakított ki.

\section{4. ÁBRA}

Románia tartományai 1960-1968

(Province-system in Romania 1960-1968)

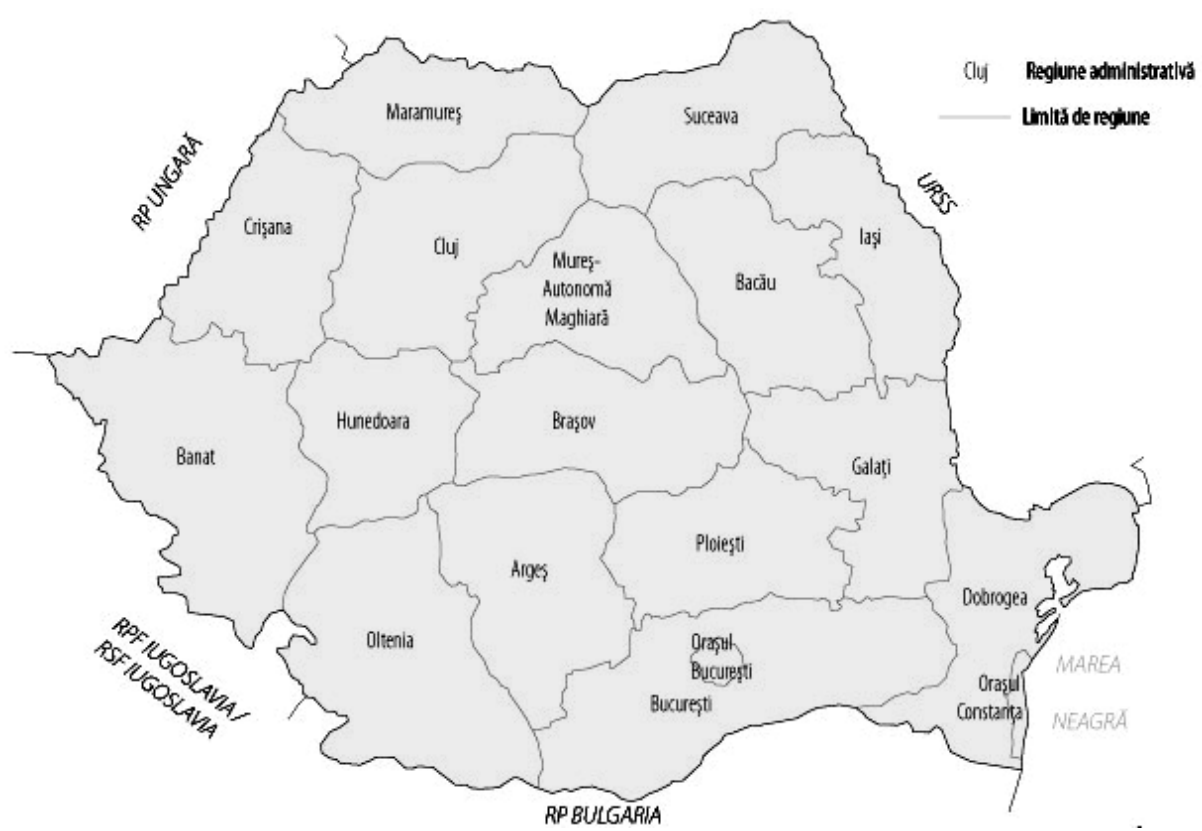

Forrás: Forrás: http://www.mdlpl.ro/_documente/atlas/.

Az 1960. évi közigazgatási reform már kifejezetten a román nemzetépítést - az egységes, homogén román nemzetállam felépítését - szolgálta. A román nemzeti törekvések agresszivitását jól mutatja, hogy 1961-ben első alkalommal neveztek ki az akkor 72\%-ban magyarlakta tartományi székhelyre, Marosvásárhelyre román városi első titkárt, és ezzel párhuzamosan megnövelték a párt- és állami vezetők között a románok arányát.

A 4. ábráról még egy fontos dolog olvasható le, a román nemzetépítés jegyében Bukarest a tartományok egy részét történelmi nevekkel látta el, így lett Erdélyben Temes tartományból Bánát (Banat), Nagyvárad tartományból Körös-vidék (Crisana), míg Nagybánya tartományból Máramaros (Maramures).

\section{A tartományi rendszer vége, az 1968. évi megyereform}

Mint a tanulmány korábbi részeiben láthattuk, Sztálin halála után (1953 márciusa) a román vezetés arra törekedett, hogy lazítsa a Szovjetuniótól való politikai és gazdasági függést. Ezen folyamat egyik fontos állomásaként 1964 áprilisában az RMP 
nyilatkozatot adott ki, melyben kinyilvánította, hogy Románia nem tür beavatkozást politikájába és megvédi szuverenitását és függetlenségét (Vincze 2005). Gyakorlatilag ez a nyilatkozat a román nemzeti érdek következetes érvényesítését jelentette be. Bár arra is fel kell hívni a figyelmet, hogy Románia a szocialista világrendszeren belül kívánt maradni, és nem kérdőjelezte meg a kommunista társadalmi berendezkedést. Ezt a kommunista-nacionalista irányvonalat Gheorgiu-Dej halála után (1965) az új főtitkár, Nicolae Ceausescu továbbvitte, sőt elődjénél keményebben érvényesítette.

Témánk, a közigazgatási térfelosztás szempontjából az államterület módosításáról elfogadott 1/1968-as törvényt kell elemeznünk. Ez a törvény ismét megváltoztatta Románia közigazgatási térfelosztását, megszüntette az 1950-ben Romániára kényszerített tartományokat, a rajon-rendszert, és visszatért a hagyományos megyerendszerhez (Vokfori 1994; 1996). A törvény három fokú közigazgatást megye-város-község - vezetett be, és a megszüntetett tartományok helyén 39 megyét állított fel (5. ábra).

\section{5. ÁBRA}

A megyék reformja 1968

(Reform of Counties 1968)

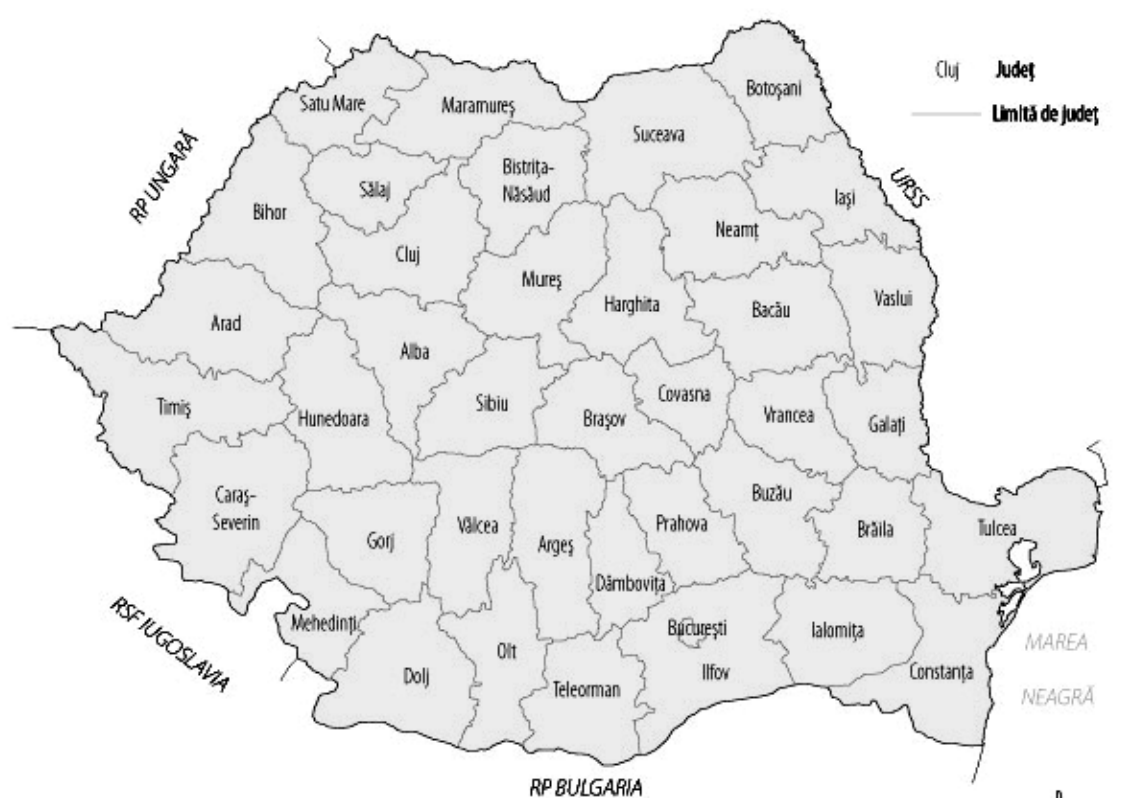

Forrás: http://www.mdlpl.ro/_documente/atlas/.

A tartományi és rajon rendszer felszámolása pontosan illeszkedett a Ceausecu-féle kommunista-nacionalista irányvonalba, egyrészt megtestesítette a Szovjetuniótól való függetlenséget, másrészt szolgálta a román államépítést. Ceausescu az 1968-as megyereform során arra törekedett, hogy erőteljesen érvényesítse a román nemzeti szempontokat - értsd a kisebbségek súlyának csökkentése -, azaz a megyék határainak meghúzásánál kifejezetten arra törekedtek, hogy olyan megyehatárokat húzzanak 
meg, melyek következtében egy-egy megyén belül csökken a magyarok részaránya. Az egykori MAT és MMAT helyén felállított három megye - Maros, Hargita, Kovászna - határainak meghúzása során komoly rendezőelv volt a nemzeti kérdés ilyen értelmezése (Sarány-Szabó 2001; Horváth 2003).

\section{Konklúziók}

Tanulmányunk záró részében két szempontból értékeljük az 1950 és 1968 között történt román közigazgatási térfelosztási kísérleteket. Egyrészt a román tartományi rendszer egésze, másrészt a magyar kisebbség szempontjából.

Ha a tartományi rendszer egészét nézzük, akkor azt rögzíthetjük, hogy Romániában a tartományi rendszer mindössze 17 évig (1950-1967) állt fenn, azaz csak rövid epizód volt a 20. századi román közigazgatási átszervezések hosszú sorában. A tartományi rendszert a román politikai elit kifejezetten szovjet mintára és nyomásra vezette be 1950-ben, és amint a szovjet nyomás csökkent és nőtt Románia kül- és belpolitikai mozgástere, felszámolta a számára idegen rajon-modellt. Ha a gazdasági oldalt vizsgáljuk, akkor azt rögzíthetjük, hogy Sztálin Romániában a „népgazdasági érdek érvényesítését" várta a rajonoktól és a tartományoktól. De valójában az elmaradott rajonok fejlettebb tartományhoz történő csatolása a Románián belül meglévő területi különbséget csak látszólag csökkentette. Sőt a nyersanyagokra épülö, extenzív ipartelepítési politika még tovább növelte a különbségeket (Vokfori 1996). A tartományi/rajon-rendszer gazdasági szempontból Romániában nem vált be, a tőle várt gyors fejlődést nem produkálta.

Ha a kérdéshez a magyar kisebbség felöl közelítünk, azt látjuk, hogy a román vezetés csak kemény szovjet nyomásra állította fel a magyar kisebbségnek autonómiát biztosító tartományt (MAT), és Sztálin halála után arra törekedett, hogy ennek működtetését formális szintre szorítsa le. Ráadásul, amint a román vezetés elég erősnek érezte magát, rögtön megszüntette a magyar autonómiát. A MAT értékelésével kapcsolatban a szakirodalomban (Schöpflin 1984; Kánya 2003; Bárdi 2005; Bottoni 2008) három tézis fogalmazódott meg: 1) Kirakat-tézis; 2) Gettó-tézis; 3) Üvegházhatás-tézis.

A kirakat-tézis szerint a MAT nem volt több, mint egy lényegtelen engedmény az elégedetlen magyar kisebbség felé (Schöpflin 1984). Ezen tézis hívei azt hangsúlyozzák, hogy egy totális kommunista diktatúrában - Románia pedig egyértelműen ennek minősíthető - elképzelhetetlen az autonómia normális müködése. Bár a MAT nevében hordozta az autonómia szót, tényleges müködésében nagyon távol állt ettől, Bukarest megmondta, hogy mit kell csinálni és a tartományi adminisztráció végrehajtotta. Ezzel párhuzamosan minden alulról jövő kezdeményezést elfojtottak.

A gettó-tézis hívei negatívan értékelik a MAT-ot (King 1973; Connor 1984; Kánya 2003). Azt fejtegetik, hogy a MAT átmenetileg és ideiglenes jelleggel javította a magyar kisebbség helyzetét a Székelyföldön, de ezzel szemben a magyar-román határ mentén, illetve Erdély más részein - különösen a Kolozsvárott - élő magyarok helyzetét kifejezetten rontotta. Egyrészt a MAT lehetőséget teremtett a románok számára, hogy 
felszámolják a Magyar Népi Szövetséget (az erdélyi magyarok érdekképviseleti szerve), mondván olyan országban, ahol a kisebbség autonómiát kap, nincs szükség önálló érdekképviseletre. Másrészt a román politikai elit a MAT segítségével a román-magyar határ mentén, továbbá a Kolozsvárott és környékén lakó magyarokat gyöngítette.

Az üvegházhatás-tézis (Bottoni 2005; 2008) abból indul ki, hogy az üvegház egy olyan szerkezet, amelynek köszönhetően az egyébként arra alkalmatlan éghajlaton lehetővé válik bizonyos növények termesztése. A MAT egy olyan üvegház volt, amely lehetővé tette a „székely kultúra” fennmaradását, sőt fejlődését. Itt kell megjegyezni, hogy jelen tanulmány szerzője ezt az üvegház-tézist hamisnak érzi, hiszen a „székely kultúra” - helyesebb volna, ha Bottoni magyar kultúráról beszélne, hiszen a székelyek is magyarok - Erdélyben tősgyökeres kultúra volt, tehát nincs szüksége üvegházra, hogy ott élhessen.

Jelen tanulmány szerzője szerint a kirakat-tézis és a gettó-tézis összeolvasztásával lehet a MAT jelentőségét értékelni. Mint azt már többször leírtuk, a MAT-ot a román kommunista vezetés kifejezetten szovjet nyomásra állította fel, de a román vezetés nagy ügyességgel még ezt a kényszert is megpróbálta saját céljainak a szolgálatába állítani. Gondoljunk arra, hogy miközben létrehozta a MAT-ot, az idő alatt Erdély más részein jelentős mértékben rontotta a magyar kisebbség helyzetét. Másrészt, amint a szovjet nyomás kisebb lett, vagy másképpen fogalmazva a román függetlenedési törekvések felerősödtek, rögtön felszámolták a magyar autonómiát.

\section{Irodalom}

A. Gergely. A. (1988) Nemzetiség és urbanizáció Romániában. Hét Torony Kiadó, Budapest.

Balogh L. (2001) Románia története. Aula, Budapest.

Bárdi N. (szerk.) (2005) Autonóm Magyarok? Székelyföld változása az „ötvenes” években. Pro Print Kiadó, Csíkszereda.

Bottoni S. (2005) A sztálini „kis Magyarország megalakítása. - Bárdi N. (szerk.) Autonóm Magyarok? Székelyföld változása az ,ötvenes” években. Pro Print Kiadó, Csíkszereda. 307-353. o.

Bottoni S. (2008) Sztálin a székelyeknél. Pro Print Kiadó, Csíkszereda.

Connor, W. (1984) The national question in Marxist-Leninist theory and strategy. Princeton University Press, Princeton.

Diószegi L-R. Süle A. (szerk.) (1990) Hetven év. A romániai magyarság története 1919-1989. Magyarságkutató Intézet, Budapest.

Gagyi J. (2005a) Magyar Autonóm Tartomány: egy centralizációs kísérlet. Hatalom értelmiség társadalom. - Bárdi N. (szerk.) Autonóm Magyarok? Székelyföld változása az „ötvenes” években. Pro Print Kiadó, Csíkszereda. 398-420. o.

Gagyi J (2005b) A szocialista modernizáció kezdetei Románia egy elmaradott régiójában. Hatalom, szakértelem, átalakulás. - Bárdi N. (szerk.) Autonóm Magyarok? Székelyföld változása az „ötvenes”, években. Pro Print Kiadó, Csíkszereda. 445-476. o.

Gagyi J. (2005c) Határ, amely összeköt. - Bárdi N. (szerk.) Autonóm Magyarok? Székelyföld változása az „ötvenes” években. Pro Print Kiadó, Csíkszereda. 354-379. o.

Hardi T.-Hajdú Z.-Mezei I. (2009) Határok és városok a Kárpát-medencében. MTA RKK, Győr-Pécs.

Horváth Gy. (szerk.) (2003) Székelyföld. A Kárpát-medence régiói 1. Dialóg Campus Kiadó, BudapestPécs.

Kánya J. (2003) Történeti áttekintés. - Horváth Gy. (szerk.) Székelyföld. A Kárpát-medence régiói 1. Dialóg Campus Kiadó, Budapest-Pécs. 27-65. o.

King, R.R. (1973) Minorities under Communism. Nationalities as a source of tension among Balkan Communist States. Harvard University Press, Cambridge. 
Miklós Gy. (1961) A Román Köztársaságban 1950 óta végrehajtott közigazgatási-gazdasági körzetbeosztás néhány tapasztalata. - Földrajzi Közlemények. 2. 307-325. o.

Molnár J. (1992) Területi-közigazgatási felosztás Erdélyben (1876-1968). - Korunk. 9. 88-97. o.

Réti T. (1990) A román tervgazdaság kialakulása 1944-1956. - Hunya G. (szerk.) Románia 1944-1990. Atlantisz-Medvetánc, Budapest. 13-47. o.

Sarány I.-Szabó K. (2001) Megyecsinálók. Hargita megye keletkezése. Státus Kiadó, Csíkszereda.

Schöpflin Gy. (1984) Magyarok Romániában. Párizsi Magyar Füzetek. 5. Párizs

Szesztay A. (2003) Nemzetiségi kérdés a Kárpát-medencében 1956-1962. MTA Kisebbségkutató Intézet, Budapest.

Vincze G. (2005) A romániai magyar kisebbség történeti kronológiája. - Bárdi N. (szerk.) Autonóm Magyarok? Székelyföld változása az „ötvenes” években. Pro Print Kiadó, Csíkszereda.

Varga E. Á. (1992) Népszámlálások a jelenkori Erdély területén. Régió Könyvek, MTA-TTI, Budapest.

Vokfori L. (1994) Erdély társadalom- és gazdaságföldrajza. Studium Kiadó, Nyíregyháza.

Vokfori L. (1996) Erdély közigazgatási földrajza. Balaton Akadémia, Vörösberény. 